\title{
THE INFLUENCE OF TRAINING, COMPETENCY, AND MOTIVATION ON THE PERFORMANCE OF THE OFFICE OF THE DJALALUDDIN AIRPORT OPERATIONAL UNIT OF GORONTALO
}

\author{
Supri' $^{1)}$, Titin Dunggio ${ }^{2)}$, and Lisda Van Gobel ${ }^{3)}$ \\ ${ }^{1,2,3)}$ Postgraduate Program of STIA Bina Taruna Gorontalo \\ E-mail: supri.ji87@gmail.com
}

\begin{abstract}
The objectives of this study were: 1) to determine and analyze the effect of training on employee performance in the Office of the Djalaluddin Airport Operational Unit of Gorontalo; 2) to determine and analyze the influence of competence on employee performance in the Office of the Djalaluddin Airport Operational Unit of Gorontalo; 3) to determine and analyze the influence of motivation on employee performance in the Office of the Djalaluddin Airport Operational Unit of Gorontalo; 4) to identify and analyze the effect of training, competence and motivation simultaneously on employee performance in the Office of the Djalaluddin Airport Operational Unit of Gorontalo.

This research uses quantitative research methods with observation data collection techniques, interviews, questionnaires, literature study and literature review. The data analysis technique used the SPSS 20 program, namely validity test, reliability test, classical assumption test and multiple linear regression analysis.

The results of the research that the researchers conducted show that: 1) there is a positive and significant influence between training variables on employee performance in the office; 2) there is a positive and significant influence between competency variables on employee performance in the Office of the Djalaluddin Airport Operational Unit of Gorontalo; 3 ) there are positive and significant influence between motivation variables on employee performance in the Office of the Djalaluddin Airport Operational Unit of Gorontalo; 4) there is a positive and significant influence simultaneously between training, competence and motivation on employee performance at the Office of the Djalaluddin Airport Operational Unit of Gorontalo.
\end{abstract}

Keywords: training, competence, motivation, employee performance

\section{INTRODUCTION}

Human resources (HR) are the main asset and have a strategic role in the organization, namely as thinkers, planners and controllers of organizational activities. Given the importance of human resources in the organization, the management of these resources is also a very important part of management work because it relates to aspects of employee performance.

Performance is the work achieved by a person or group of people in an organization, according to their respective authorities and responsibilities in an effort to achieve the goals of the organization concerned legally, does not violate the law, and is in accordance with morals [4].

Submit: Oct. $16^{\text {th }}, 2020$

Accepted: Dec. $5^{\text {th }}, 2020$

Published: Dec. $17^{\text {th }}, 2020$

Journal of Economics, Business and Administration (JEBA) - E-ISSN: 2746-1688 1 
Employee performance so far seems less than optimal. This is based on data presented by the Ministry of Administrative and Bureaucratic Reform (Kemenpan-RB) in 2018 that around 30\% or 1.35 million civil servants are classified as underperforming [1]. And also expressed by the Deputy for Bureaucratic Reform, Apparatus Accountability and Supervision of Kemenpan-RB Muhammad Yusuf Ateh in the evaluation of the Government Agency Performance Accountability System (SAKIP) and Bureaucratic Reform in Semarang that there are still many employees who have not worked optimally, do not know their duties and obligations in works [19].

Based on the results of preliminary observations made by researchers at the Office of the Djalaluddin Airport Operational Unit of Gorontalo, it cannot be separated from employee performance problems. The employee performance problems include: 1) there are still many employee work targets that have not been achieved; 2) there are still many employees who do not have the ability in accordance with their main duties and functions; 3) there are still many employees who often postpone work; 4) there are still employees who are not focused on doing work; 5) there are still employees who have not been able to make performance reports through the application; 6) there are still many employees who are not committed to work discipline.

From several obstacles and shortcomings that can reduce employee performance, it is necessary to address them to further improve employee performance. In improving employee performance, agencies must be able to find out what factors can affect employee performance. Several factors that can affect employee performance are training, competence and motivation. With maximum training and competence and high work motivation, it is hoped that employee performance can continue to increase so that the goals of the institution can be achieved.

Starting from the above background, the researcher is interested in making a study entitled: The Effect of Training, Competence, and Motivation on Employee Performance in the Office of the Djalaluddin Airport Operational Unit of Gorontalo.

\section{Public Administration Science}

Public administration is all administrative activities for all public affairs (administration for the public affairs) [9]. In addition, public administration can be defined as a study of various government agencies organized, equipped with their personnel, financed and led and cooperating administratively to achieve goals [2].

\section{Human Resource Management}

Human resource management is a human resource management system that is formal in nature and pays attention to effective and efficient aspects of the organization to achieve organizational goals [13]. In addition, human resource management can be interpreted as a science or a way of how to manage the relationships and roles of resources (labor) owned by individuals efficiently and effectively and can be used optimally so that maximum goals can be achieved by the organization, employees and society [3].

\section{Training}

Training Is an effort planned by the organization to facilitate the learning of employee competencies related to work. Competencies include knowledge, skills and behaviors that are considered important or have a direct effect on employee work productivity [12]. In addition, training can also be defined as a series of activities designed to improve 
one's skills, knowledge, experience or change in attitudes [3]. Training indicators in this study consist of:

1. Participation, which is followed by employees in an organization, especially followed by employees who need training to support their careers in the organization. In addition, in training there are trainers who are assigned to conduct training for training participants.

2. Training materials must be prepared and adapted to training needs.

3. The level of difficulty must be adjusted to the needs of employees, namely the needs of employees to increase the ability to face job difficulties.

4. Transfer of transfer, namely the transfer of knowledge from the trainer to the training participants which will later be useful in increasing the ability of employees [15].

\section{Competence}

Competence can be described as the ability to integrate knowledge, skills, attitudes and personal values, and the ability to build knowledge and skills based on experience and learning carried out [11]. In addition, competence is also defined as a person's ability that can be observed which includes knowledge, skills, and attitudes in completing a job or task in accordance with the specified performance [14].

Competency indicators in this study consist of:

1. Work related knowledge:

a. Knowing and understanding knowledge in their respective fields regarding their duties and responsibilities at work.

b. Knowing the knowledge related to regulations, procedures, new techniques in the organization.

c. Know how to use correct and correct information, tools and techniques.

2. Individual skills include: a. Ability to communicate well in writing.

b. Ability to communicate clearly in verbal.

3. Work attitudes include:

a. Have the ability to be creative at work.

b. Having high morale.

c. Having skills in planning/organizing [5].

\section{Motivation}

Motivation is defined as a skill, in directing employees and organizations to want to work successfully, so that the desires of employees and organizational goals are achieved at the same time [8]. In addition, work motivation is also defined as individual motivation that moves employees who are directed or aimed at achieving organizational goals [9].

Indicators of work motivation in this study consisted of:

1. The relationships with coworkers and superiors, namely the existence of a harmonious atmosphere between employees and the establishment of cooperation between subordinates and superiors and colleagues.

2. Work environment, namely the existence of adequate work support facilities in accordance with work needs and a work atmosphere as expected.

3. The opportunity to increase knowledge and skills is that the organization always provides education and training for its employees.

4. Giving allowances, namely the organization must provide adequate allowances for its employees [10].

\section{Performance}

Performance is the end point of certain people, resources, and the environment that are gathered together with the intention of producing certain 
things, whether visible products or services that are less direct [17]. In addition, performance is defined as a goaloriented process that is directed to ensure that organizational processes are created to maximize the productivity of employees, teams, and organizations [16].

Employee performance indicators in this study consist of:

1. Work quality is measured by employees' perceptions of the quality of work produced as well as the perfection of tasks on the skills and abilities of employees.

2. Quantity is the amount produced expressed in terms such as the number of units, the number of activity cycles completed.

3. Timeliness is the level of activity completed at the beginning of the stated time, seen from the point of coordination with the output results and maximizing the time available for other activities.

4. Effectiveness is the level of use of organizational resources (manpower, money, technology, raw materials) maximized with the intention of increasing the results of each unit in the use of resources.

5. Independence is the level of an employee who will later be able to carry out their work functions.

6. Work commitment is a level where employees have a commitment to work with the agency and employee responsibilities to the office [7].

\section{RESEARCH METHODS}

This study is titled The Effect of Training, Competence and Motivation on Employee Performance in the Organizing Unit Office of Djalaluddin Airport of Gorontalo. The approach used in this research is a survey approach and the type of research is quantitative research.

Quantitative research is a research approach that primarily uses the propositivism paradigm in the development of science (such as thinking about cause and effect, reduction to variables, hypotheses and specific questions, using measurement and observation and theory testing) using research strategies such as experiments and surveys that require data statistics [6].

This research was conducted for 2 months from September to October 2020.

\section{Sources of Data}

Sources of data used in the study are primary data and secondary data as follows:

1. Primary data is data obtained by field surveys that use all original data collection methods such as distributing questionnaires and conducting direct interviews with parties related to the research being carried out, namely leaders and employees of the Organizing Unit Office of Djalaluddin Airport of Gorontalo.

2. Secondary data is data that has been collected by data collection agencies and published to users in the form of books, journals and other documents related to the research title [18].

\section{Population and Sample}

In this study, researchers used a population of all civil servants who worked in the Organizing Unit Office of Djalaluddin Airport of Gorontalo as many as ninety-two (92) people. The sample who became the respondents in this study was saturated sampling or census research of ninety-two (92) respondents.

\section{Data Collection Technique}

The data collection technique in this research is by conducting field research which includes direct observation at the Organizing Unit Office of Djalaluddin Airport of Gorontalo, interviews with personnel managers and the part deemed necessary to be interviewed, questionnai- 
The Influence of Training, Competency, and Motivation on the Performance of the Office of the Djalaluddin Airport Operational Unit Of Gorontalo

res are distributed to 92 civil servants who work in the Organizing Unit Office of Djalaluddin Airport of Gorontalo and literature studies conducted to gather information relevant to the topic or issue that will be or is being researched.

\section{Data Analysis Technique}

In conducting descriptive statistical analysis, researchers used the SPSS 20 application.

1. Validity test

2. Reliability Test

3. Classical Assumption Test

\section{Multiple Regression Analysis}

By using the general form of the multiple regression equation used in this study are as follows:

$\mathrm{Y}=\alpha+\beta 1 \mathrm{x} 1+\beta 2 \times 2+\beta 3 \times 3+\varepsilon$

Information :

$\mathrm{Y} \quad$ : Employee Performance

$\alpha \quad$ : Constant

X1 : Training

X2 : Competence

X3 : Motivation

$\beta 1, \beta 2, \beta 3$ : the amount of the regression coefficient of each variable

$\varepsilon \quad$ : error

\section{Hypothesis Testing}

Hypothesis testing in this study aims to determine whether or not there is a significant influence between the independent variables, namely training, competence, and motivation on the dependent variable, namely employee performance either partially or simultaneously.

RESULT AND DISCUSSION

Variable Validity Testing

Table 1. Results of Validity Test of the Training Variables

\begin{tabular}{cccc} 
Statement & $\mathbf{R}_{\text {table }}$ & $\mathbf{R}_{\text {count }}$ & Note \\
\hline X1.1 & 0,2050 & 0,723 & Valid \\
\hline
\end{tabular}

\begin{tabular}{cccc}
\hline X1.2 & 0,2050 & 0,727 & Valid \\
\hline X1.3 & 0,2050 & 0,708 & Valid \\
\hline X1.4 & 0,2050 & 0,702 & Valid \\
\hline X1.5 & 0,2050 & 0,727 & Valid \\
\hline X1.6 & 0,2050 & 0,795 & Valid \\
\hline X1.7 & 0,2050 & 0,865 & Valid \\
\hline X1.8 & 0,2050 & 0,851 & Valid \\
\hline X1.9 & 0,2050 & 0,732 & Valid \\
\hline X1.10 & 0,2050 & 0,837 & Valid \\
\hline X1.11 & 0,2050 & 0,851 & Valid \\
\hline
\end{tabular}

Tabel 2. Results of Validity Test of the Competency Variables

\begin{tabular}{cccc}
\hline Statement & $\mathbf{R}_{\text {table }}$ & $\mathbf{R}_{\text {count }}$ & Note \\
\hline X2.1 & 0,2050 & 0,789 & Valid \\
\hline X2.2 & 0,2050 & 0,783 & Valid \\
\hline X2.3 & 0,2050 & 0,814 & Valid \\
\hline X2.4 & 0,2050 & 0,745 & Valid \\
\hline X2.5 & 0,2050 & 0,750 & Valid \\
\hline X2.6 & 0,2050 & 0,727 & Valid \\
\hline X2.7 & 0,2050 & 0,854 & Valid \\
\hline X2.8 & 0,2050 & 0,860 & Valid \\
\hline X2.9 & 0,2050 & 0,830 & Valid \\
\hline X2.10 & 0,2050 & 0,803 & Valid \\
\hline X2.11 & 0,2050 & 0,823 & Valid \\
\hline X2.12 & 0,2050 & 0,830 & Valid \\
\hline
\end{tabular}

Table 3. Results of the Validity Test of Motivation Variables

\begin{tabular}{cccc}
\hline Statement & $\mathbf{R}_{\text {table }}$ & $\mathbf{R}_{\text {count }}$ & Note \\
\hline X3.1 & 0,2050 & 0,768 & Valid \\
\hline X3.2 & 0,2050 & 0,774 & Valid \\
\hline X3.3 & 0,2050 & 0,782 & Valid \\
\hline X3.4 & 0,2050 & 0,729 & Valid \\
\hline X3.5 & 0,2050 & 0,879 & Valid \\
\hline X3.6 & 0,2050 & 0,837 & Valid \\
\hline X3.7 & 0,2050 & 0,863 & Valid \\
\hline X3.8 & 0,2050 & 0,847 & Valid \\
\hline X3.9 & 0,2050 & 0,816 & Valid \\
\hline X3.10 & 0,2050 & 0,810 & Valid \\
\hline
\end{tabular}

Table 4. Results of the Validity Test of Performance Variables

\begin{tabular}{cccc}
\hline Statement & $\mathbf{R}_{\text {table }}$ & $\mathbf{R}_{\text {count }}$ & Note \\
\hline Y.1 & 0,2050 & 0,770 & Valid \\
\hline Y.2 & 0,2050 & 0,738 & Valid \\
\hline Y.3 & 0,2050 & 0,787 & Valid \\
\hline Y.4 & 0,2050 & 0,834 & Valid \\
\hline
\end{tabular}


The Influence of Training, Competency, and Motivation on the Performance of the Office of the Djalaluddin Airport Operational Unit Of Gorontalo

\begin{tabular}{cccc}
\hline Y.5 & 0.2050 & 0,823 & Valid \\
\hline Y.6 & 0,2050 & 0,682 & Valid \\
\hline Y.7 & 0,2050 & 0,645 & Valid \\
\hline Y.8 & 0,2050 & 0,687 & Valid \\
\hline Y.9 & 0,2050 & 0,794 & Valid \\
\hline Y.10 & 0,2050 & 0,805 & Valid \\
\hline Y.11 & 0,2050 & 0,857 & Valid \\
\hline Y.12 & 0,2050 & 0,781 & Valid \\
\hline Y.13 & 0,2050 & 0,767 & Valid \\
\hline Y.14 & 0,2050 & 0,717 & Valid \\
\hline Y.15 & 0,2050 & 0,689 & Valid \\
\hline Y.16 & 0,2050 & 0,816 & Valid \\
\hline Y.17 & 0,2050 & 0,749 & Valid \\
\hline Y.18 & 0,2050 & 0,793 & Valid \\
\hline Y.19 & 0,2050 & 0,754 & Valid \\
\hline Y.20 & 0,2050 & 0,740 & Valid \\
\hline
\end{tabular}

Reliability Testing

Tabel 5. Reliability Test Results

\begin{tabular}{cccc}
\hline Variables & $\mathbf{r} \boldsymbol{\alpha}$ tablel & $\mathbf{r} \boldsymbol{\alpha}$ count & Note \\
\hline Training & 0,60 & 0,933 & Reliabel \\
\hline Competence & 0,60 & 0,948 & Reliabel \\
\hline Motivation & 0,60 & 0,940 & Reliabel \\
\hline Performance & 0,60 & 0,962 & Reliabel \\
\hline
\end{tabular}

From the table above, based on processed data using SSS 20, Cronbach's Alpha value $>0.60$, this shows that all measurement concepts for each variable of the questionnaire are reliable, which means that the questionnaire used in this study is a reliable questionnaire. The instrument used was 53 question items with 92 respondents being declared reliable.

\section{Classical Assumption Test}

1. Normality Test

The normality test is used to determine whether a variable is normally distributed or not and aims to find out how much data is generally distributed to the variables used in this study. The results of the data normality test are as follows:

Table 6. Sample Kolmogorov-

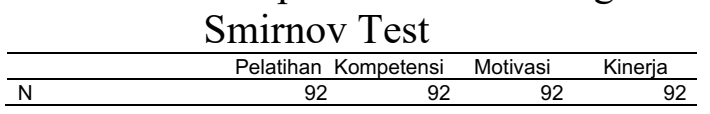

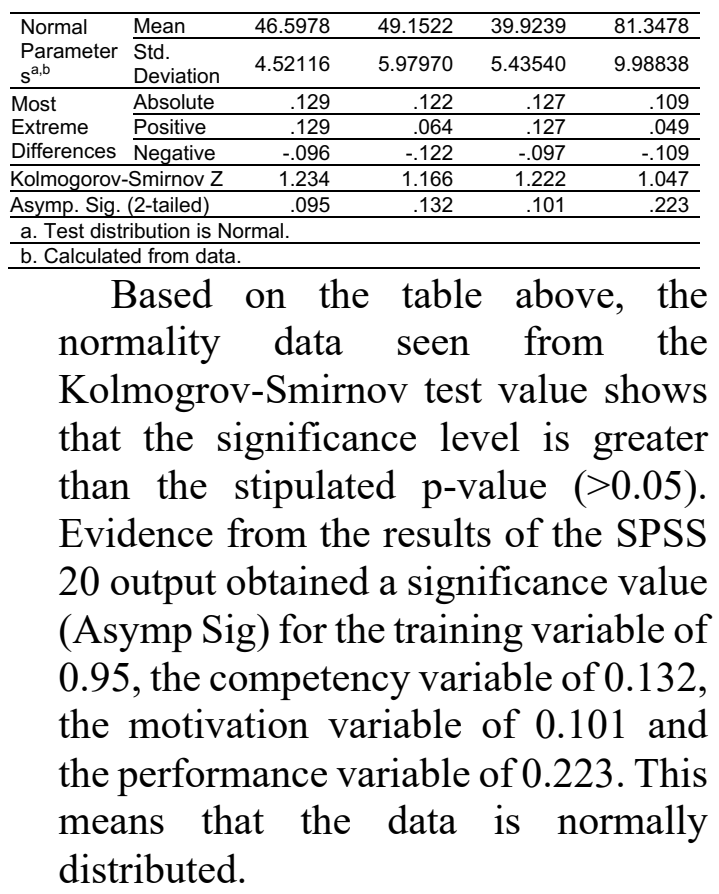

2. Heteroscedasticity Test

The heteroscedasticity test aims to test whether the regression model has an inequality of variants from one observation to another. The results of the SPSS 20 test obtained the following data:

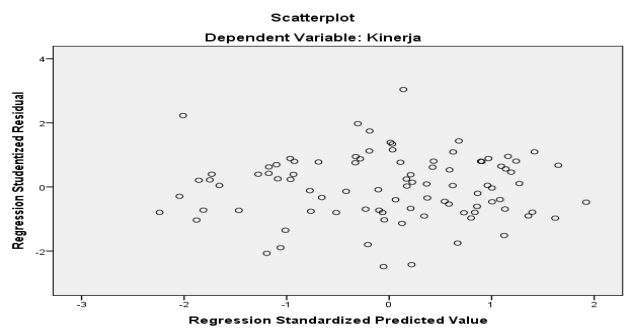

Figure 1. Heteroscedasticity Test

From the scatterplot graph in the image above, it can be seen that the dots are spreading randomly and do not appear to be forming a certain clear pattern so that the regression model is feasible to be used.

\section{Multiple Linear Regression}

Multiple linear regression aims to see the relationship between more than one independent variable and the dependent variable. In this study, there are three independent variables, namely training ( $\mathrm{X}$ 
training (X1), competence (X2) and motivation (X3) and one dependent variable, namely employee performance (Y). The results of the analysis use SPSS 20 software. As follows:

Table 7. Coefficients ${ }^{\mathrm{a}}$

\begin{tabular}{lrrrrr}
\hline Model & \multicolumn{2}{c}{$\begin{array}{c}\text { Unstandardized } \\
\text { Coefficients }\end{array}$} & $\begin{array}{c}\text { Standardized } \\
\text { Coefficients }\end{array}$ & T & Sig. \\
\cline { 2 - 5 } & $\mathrm{B}$ & $\begin{array}{c}\text { Std. } \\
\text { Error }\end{array}$ & Beta & & \\
\hline (Constant) & -1.754 & 5.435 & & & \\
\hline Pelatihan & .417 & .152 & .323 & .748 \\
\hline Kompetensi & .763 & .140 & .457 & 2.752 & .007 \\
\hline Motivasi & .656 & .128 & .357 & 5.116 & .000 \\
\hline a. Dependent Variable: Kinerja & & & & .000 \\
\hline
\end{tabular}

From the table above, the regression model formed is $\mathrm{Y}=-1.754+0.417 \mathrm{X} 1$, $+0.763 \mathrm{X} 2+0.656 \mathrm{X} 3$. From this model it can be concluded that there is a positive influence between training, competence and motivation on employee performance. Besides that, it is also seen a constant value which means that if the training, competency and motivation variables do not have a distribution or value of 0 , the employee's performance will decrease by $=-1.754$.

\section{Hypothesis Testing}

\section{Partial T Test}

The $t$ test aims to test the effect of the independent variable partially on the dependent variable. This test is carried out with the $t$ test at the 95\% confidence level. If the $t$ value is greater than $t$ table and the significance value is less than 0.05 , it can be concluded that the independent variable partially influences and is significant on the dependent variable.

Based on the test results it can be concluded as follows:

a. Training Variable

The test results obtained by the $\mathrm{t}$ value of the employee training variable $=8.396>\mathrm{t}$ table $(0.05)(90)$ $=0.166$ with a significance value $=$ $0.00<0.05$, this means that the hypothesis that training has an influence on employee performance received. b. Competency Variable

The test results show that the $\mathrm{t}$ value of the employee competency variable is $=14.086>\mathrm{t}$ table $(0.05)$ $(90)=0.166$ with a significance value $=0.00<0.05$, so this means that the hypothesis which states that competence has an influence on employee performance received.

c. Motivation Variable

The test results obtained that the $t$ value of the employee motivation variable is $=11.043>\mathrm{t}$ table $(0.05)$ $(90)=0.166$ with a significance value $=0.00<0.05$, so this means that the hypothesis that motivation has an influence on employee performance .

2. The F Test

The $\mathrm{F}$ test aims to find out how far all the independent variables together can influence the dependent variable.

Based on the results of testing the training, competence and motivation variables simultaneously on employee performance, it is obtained that the value of $F$ count $=100.747$ with a significance of $0.000<0.05$. Where Ftable $(0.95)(2.89)=3.10$. Thus the value of $\mathrm{F}$ count $>\mathrm{F}$ table, this means that the hypothesis which states that training, competence and motivation simultaneously have an influence on employee performance.

3. Analysis of Correlation Coefficientcy and Determination

The results of the analysis of correlation coefficientcy and determination in the study are as follows:

\section{a. Influence of Training}

The test results show that the correlation coefficient (R) of 0.663 means that it has a strong and 
The Influence of Training, Competency, and Motivation on the Performance of the Office of the Djalaluddin Airport Operational Unit Of Gorontalo

positive relationship between training variables and employee performance. Meanwhile, the coefficient of determination (R2) which is equal to 0.4396 means that the contribution of the training effect on employee performance is $43.96 \%$, while the remaining $56.04 \%$ is influenced by other variables not examined in this study.

b. Influence of Competence

The test results show that the correlation coefficient (R) of 0.829 means that it has a very strong and positive relationship between the competency variable and employee performance. Meanwhile, the coefficient of determination (R2) is 0.6872 which means that the contribution of the influence of competence on employee performance is $68.72 \%$ while the remaining $31.28 \%$ is influenced by other variables not examined in this study.

c. Influence of Motivation

The test results show that the correlation coefficient (R) of 0.759 means that it has a strong and positive relationship between motivation and employee performance. While the value of the coefficient of determination (R2) is 0.5761 , this means that the contribution of the influence of motivation on employee performance is $57.61 \%$ while the remaining $42.39 \%$ is influenced by other variables not examined in this study.

d. Influence of Training, Competence, and Motivation

The test results show that the correlation coefficient $(\mathrm{R})$ of 0.880 means that it has a very strong and positive relationship between training, competence and motivation variables simultaneously with employee performance. Meanwhile, the coefficient of determination (R2) which is equal to 0.7744 means that the contribution of the effect of training, competence and motivation simultaneously to employee performance is $77.44 \%$, while the remaining $22.56 \%$ is influenced by other variables not examined in this study.

\section{DISCUSSION}

\section{Influence of Training}

Training is an important factor in increasing employee productivity. Where by following employee training will gain knowledge, skills and work behavior that will have a direct impact on work productivity.

The results of hypothesis testing show that training has a positive and significant effect on employee performance with a value of tcount $>$ ttable (0.05) (90) $=$ $8.396>0.166$ and a correlation value (r) of $=0.663$ which means positive and strong, while the coefficient of determination is $43,96 \%$. This means that training has a real impact on employee performance at the Organizing Unit Office of Djalaluddin Airport of Gorontalo. So the hypothesis which states that training has a positive and significant effect on employee performance is proven.

The contribution or influence given by training on employee performance is $\mathrm{KD}=43.96 \%$. The remaining $56.04 \%$ is certainly influenced by other factors. This is supported by the percentage descriptive analysis where it is known that the training variable is predominantly in the good category, which is seen from the eleven statements, six in the good category and five in the very good category. The results of the research are in line with what has 
been done by the Organizing Unit Office of Djalaluddin Airport of Gorontalo to its employees where the Organizing Unit Office of Djalaluddin Airport of Gorontalo often sends its employees to the Human Resource Development on Transportation Agency to attend job training.

Based on the training data for Civil Servants (attached) at the Organizing Unit Office of Djalaluddin Airport of Gorontalo in the last three years who attended training on average every year as many as 20 people or $21.74 \%$. This implies that the better the training, the better the employee's performance. By participating in a training program, employees will increase participation, mastery of training materials, and increase their ability to work so that they can improve their work performance. Employee performance can be improved through relevant training according to agency needs.

\section{Influence of Competence}

Competence is an important factor to increase employee productivity. A competent employee will have the ability to integrate knowledge, skills, attitudes and values based on their experience and learning.

The results of hypothesis testing prove that competence has a positive and significant effect on employee performance with tcount $>$ table $(0.05)$ $(90)=14.086>0.166$ and the correlation value $r=0.829$ means (positive and very strong) so that the coefficient of determination is $68,72 \%$. This means that competence has a real impact on employee performance in the Organizing Unit Office of Djalaluddin Airport of Gorontalo.

The contribution of influence given by competence to employee performance is $68.72 \%$, the remaining $31.28 \%$ is certainly influenced by other factors, both from internal and external factors of the employees themselves. This is supported by the percentage descriptive analysis where it is known that the competency variable is dominantly in the good category, which is seen from twelve statements, seven are in the good category and five are in the very good category.

In addition, it is also supported by the characteristics of respondents based on the field of duty and education level of the Office of the Organizing Unit Office of Djalaluddin Airport of Gorontalo, where in the field of administrative duties the majority of employees have formal Diplomas and Bachelor as well as Masters while for operations the majority only have formal high school education.

In supporting the improvement of the competency of the employees of the Office of the Organizing Unit Office of Djalaluddin Airport of Gorontalo apart from formal education, such as by providing recommendations to attend undergraduate or postgraduate education but also supporting employees to take technical training conducted by the Human Resource Development on Transportation Agency. This is done to gain knowledge, skills and work attitudes at work so that with the competencies possessed, employee performance will be better.

\section{Influence of Motivation}

Motivation is one of the important factors to increase employee productivity. Where work motivation is a skill in directing employees and organizations to be successful at work, so that employees' targets and organizational goals are achieved at the same time [8].

The results of hypothesis testing prove that motivation has a positive and significant impact on employee performance with $\mathrm{t}$ count $>\mathrm{t}$ table $(0.05)$ $(90)=11.043>0.166$ and the correlation value $\mathrm{r}=0.759$ means (positive and 
strong) and the coefficient of determination is $57.61 . \%$. This means that motivation has a real impact on employee performance in the Organizing Unit Office of Djalaluddin Airport of Gorontalo.

The contribution or contribution of influence given by motivation to employee performance is $57.61 \%$, the remaining $42.39 \%$ is certainly influenced by other factors, both internal factors and external factors from the employees themselves. This is supported by the percentage descriptive analysis where it is known that the motivation variable is predominantly in the good category, which is seen from ten statements, six in the good category and four in the very good category. In addition, the Office of the Organizing Unit Office of Djalaluddin Airport of Gorontalo always supports its employees by providing proper and comfortable working facilities such as terminal buildings, office space and sports venues as well as other supporting facilities. In addition, the Djalaluddin Gorontalo Airport Management Unit Office always provides decent work allowances to employees so that employees are motivated to work.

\section{Influence of Training, Competence and Motivation}

Performance is the work achieved by a person or group of people in an organization, according to their respective authorities and responsibilities in an effort to achieve the goals of the organization concerned legally, does not violate the law, and is in accordance with morals [4]. The factors that affect employee work, namely: knowledge, skills, abilities, experience, self-confidence, motivation and commitment of each individual. Training will increase knowledge, skills and also increase competence both formal and non-formal knowledge.
The results of hypothesis testing prove that the combination of training, competence and motivation has a positive and significant impact on employee performance with a value of Fcount $=$ 100.747 or a correlation value of $r=0.880$, this means that the higher the training, competence and motivation given to employees, the higher the employee performance. the Office of the Organizing Unit Office of Djalaluddin Airport of Gorontalo. Likewise, on the other hand, the lower the training, competence and motivation together for employees, the lower the performance of employees in the Organizing Unit Office of Djalaluddin Airport of Gorontalo.

The effect contribution given by training, competence and motivation in total to employee performance is $77.44 \%$ and the remaining $22.56 \%$ is certainly influenced by other factors that are not discussed in this study. This is supported by the percentage descriptive analysis where it is known that the performance variables are predominantly in the good category, which is seen from twenty statements, eleven in the good category and nine in the very good category.

In addition, there are another factor that support the performance of the employees of the Organizing Unit Office of Djalaluddin Airport of Gorontalo office. It can be seen from the characteristics of respondents based on the age and years of service of the employees. Where employees who work at the Organizing Unit Office of Djalaluddin Airport of Gorontalo office are in a productive period, namely the age between $25-45$ years as many as 82 people or $89.13 \%$. Meanwhile, based on tenure, the majority of employees of the Organizing Unit Office of Djalaluddin Airport of Gorontalo office have worked for more than 5 years.

This is beneficial for the institution, because by providing training, there will

E-ISSN: 2746-1688, Vol. 1, No. 2, Dec. (2020), pp. 1-12 https://journals.ubmg.ac.id/index.php/JEBA/ Journal of Economics, Business and Administration (JEBA) 
be an increase in employee competence and motivation for employees of productive age and also make them have sufficient work experience which will further increase knowledge, skills, work attitudes and emotional maturity in building good relationships between colleagues. work as well as superiors in daily work life so that the level of productivity will be higher in terms of quality, quantity, timeliness, effectiveness, independence and commitment.

\section{CONCLUSION}

1. Training (X1) has a strong and positive effect towards employee performance (Y) at the Organizing Unit Office of Djalaluddin Airport, Gorontalo office of 0.4396 or $43.96 \%$. This means that training that is carried out continuously can have a real impact on improving employee performance at the Organizing Unit Office of Djalaluddin Airport, Gorontalo.

2. Competence (X2) has a very strong and positive effect towards employee performance (Y) at the Djalaluddin Gorontalo Airport Management Unit office at 0.6872 or $68.72 \%$. This means that competencies that are developed in a sustainable manner will have a real impact on improving employee performance at the Organizing Unit Office of Djalaluddin Airport, Gorontalo.

3. Motivation (X3) has a strong and positive effect towards employee performance $(\mathrm{Y})$ at the Djalaluddin Gorontalo Airport Management Unit office at 0.5761 or $57.61 \%$. This means that the motivation given continuously will have a real impact on improving employee performance at the Organizing Unit Office of Djalaluddin Airport, Gorontalo.
4. Training (X1), Competence (X2) and Motivation (X3) simultaneously have a very strong and positive effect towards employee performance (Y) at the Djalaluddin Gorontalo Airport Organizing Unit office of 0.7744 or $77.44 \%$. This means that training is carried out continuously and competencies that are always developed in a sustainable manner as well as continuous motivation will have an impact on improving the performance of employees at the Organizing Unit Office of Djalaluddin Airport, Gorontalo.

Researchers suggest to the head of the Organizing Unit Office of Djalaluddin Airport of Gorontalo to carry out continuous employee training, always improve employee competence and continuously motivate employees to create optimal employee performance.

Researchers suggest that employees of the Organizing Unit Office of Djalaluddin Airport, Gorontalo to always increase their participation in training and develop their competencies continuously, whether it is formal education or nonformal education such as technical training and maintain their motivation so that their performance can be more optimal.

\section{REFERENCES}

[1] Antoni, A., Angga, D., dan Akmal, M. (2018). 1,35 Juta PNS Berkinerja Buruk. Sindonews. 15 November 2018.

[2] Congge, U. (2017). Patologi Administrasi Negara. SAH Media. Makassar.

[3] Evanita, L. (2013). Disiplin Kerja, Gaya Kepemimpinan, Pelatihan Dan Kinerja Karyawan Rsud Lubuk Sikaping. Tesis. Universitas Esa Unggul. Jakarta. 
The Influence of Training, Competency, and Motivation on the Performance of the Office of the Djalaluddin Airport Operational Unit Of Gorontalo

[4] Fauzi, A. dan Nugroho, R. H. (2020). Manajemen Kinerja. Erlangga. Surabaya.

[5] Ginanti, M. G. (2017). Analisis Pengaruh Kompetensi, Pelatihan Dan Kompensasi Terhadap Kinerja Karyawan Dengan Kepuasan Kerja Sebagai Variabel Intervening Pada Tim Tanggap Darurat Fire And EmergencyServices Di Wilayah Kerja Tambang PT. Vale Ind. Tbk. Thesis. Universitas Hasanuddin. Makassar.

[6] Hermawan, I. (2019). Metodologi Penelitian Pendidikan. Hidayatul Quran. Kuningan.

[7] Kristanti, D. dan Pangastuti, R. L. (2019). Kiat-kiat merangsang kinerja, Media Sahabat Cendekia. Surabaya.

[8] Mamik. (2016). Manajemen Sumber Daya Manusia. Zifatama Jawara. Sidoarjo.

[9] Mindarti, L. I. (2016). Aneka Pendekatan dan Teori Dasar Administrasi Publik. UB Press. Malang.

[10]Nawastuti, R. (2018). Pengaruh Motivasi Dan Kompensasi Terhadap Kinerja Karyawan Dengan Kepuasan Kerja Sebagai Variabel Intervening (Studi Kasus Pada Pt. Bank Tabungan Negara Tbk. Kantor Cabang Syariah Semarang). Skripsi, Institut Agama Islam Negeri Salatiga, Semarang.

[11]Nyoto. (2019). Manajemen Sumber Daya Manusia. Uwais Inspirasi Indonesia. Ponorogo.
[12]Priansa, D. J. (2017). Manajemen Kinerja Pegawai Dalam Pengelolaan SDM Perusahaan. Pustaka Setia. Bandung.

[13] Riniwati, H. (2016). Manajemen Sumber Daya Manusia. UB Press. Malang.

[14] Riyanto, S. dan Hatmawan, A. A. (2020). Metode Riset Penelitian Kuantitatif. Budi Utama. Yogyakarta.

[15] Sudarsono, S. S., Kamase, J., Ella, H., Rachman, A., \& Dunggio, T. (2020). Big data and content marketing on purchase decisions online in Indonesia. IOSR Journal Of Business And Management (IOSR$J B M), 22(2), 42-46$.

[16] Sudaryo, Y., Ariwibowo, A. dan Sofiati, N. A. (2018). Manajemen Sumber Daya Manusia, Kompensasi Tidak Langsung dan Lingkungan Kerja Fisik. ANDI. Yogyakarta.

[17] Suryani N. K. dan FoEh. J. (2019). Manajemen Sumber Daya Manusia, Tinjauan Praktis Aplikatif. Nilacakra. Bali.

[18] Wandarita, R. (2017). Kepuasan Kerja \& Kinerja Pegawai. Elmatera. Yogyakarta.

[19] Yulianto, A. B., Maskan, M. dan Utaminingsih, A. (2018). Metodologi Penelitian Bisinis. Polinema Press. Malang.

[20] Rujukan Web https://economy.okezone.com $/ \mathrm{read} / 2$ 020/03/11/320/2181872/11-7instansi-pemerintah-dinilai-burukdalam-manajemen-kinerja-pns). 